\title{
RHODODENDRON GUMINEENSE CRAVEN (ERICACEAE, SUBGENUS VIREYA), A NEW RECORD FOR INDONESIA
}

\author{
Yasper Michael Mambrasar \\ Herbarium Bogoriense, Botany Division, Research Center for Biology-LIPI, Cibinong Science Center, Jln. \\ Raya Jakarta-Bogor Km. 46, Cibinong 16911, Bogor, Indonesia. \\ E-mail: michael_mambrasar@yahoo.com
}

Yasper Michael Mambrasar. 2018. Rhododendron gumineense Craven (Ericaceae, Submarga Vireya), Rekaman Baru untuk Indonesia. Floribunda 6(1): 19-21. - Jumlah jenis Rhododendron di Indonesia dilaporkan sebanyak 229 jenis. Satu jenis Rhododendron dari Lembah Baliem, Indonesia yang sebelumnya diidentifikasi sebagai Rhododendron beyerinckianum Koord. telah diidentifikasi sebagai Rhododendron gumineense Craven, berdasarkan bentuk daun dan tangkai putik. Sehingga menambah jumlah jenis Rhododendron di Indonesia menjadi 230.

Kata Kunci: Indonesia, Lembah Baliem, Rekaman baru, Rhododendron.

Yasper Michael Mambrasar. 2018. Rhododendron gumineense Craven (Ericaceae, Subgenus Vireya), a new record for Indonesia. Floribunda 6(1): 19-21. - The number of Rhododendron species in Indonesia was reported as 229 species. A specimen of Rhododendron from the Baliem valley, Indonesia previously identified as Rhododendron beyerinckianum Koord. has been identified as Rhododendron gumineense Craven, based on leaf shape and style morphology. This increases the number of Rhododendrons in Indonesia to 230 species.

Keywords: Indonesia, Baliem valley, New record, Rhododendron.

Indonesia is the second richest country in the diversity of Rhododendrons after China (MacKay \& Gardiner 2017, Gibbs et al 2011). There are presently 229 species spread through Sumatra, Java, Lesser Sunda Island (LSI), Borneo, Moluccas, and Papua (Sleumer 1966, Gibbs et al. 2001, Argent 2006, Argent 2015). Papua has the highest diversity of Rhododendron compared with the other Indonesian Islands. Argent (2015) records 171 species in New Guinea as a whole. 121 species in the western half of New Guinea and 85 in the eastern. It is estimated that the number of Rhododendron species in the western part will increase because many areas have not been explored as much as the eastern Part (Kartikasari et al. 2013).

Information about the existence of Rhododendron in Papua begins with discovery four species of Rhododendron on Mts. Arfak in 1875 recorded by Odoardo Beccari (Beccari 1878). After Beccari, more new species of Rhododendron were described from specimens collected by botanists or naturalists from Holland, America, Belgium, French, Spanish, and Australia (Kartikasari et al. 2013, Steenis-Kruseman 1950). Information about Rhododendron in the western part of New Guinea declined after the Dutch passed Papua to Indonesia in 1 May 1963 due to decreased botanical exploration. In the eastern part, botanical exploration continued after Papua New Guinea gained independence from Australia in 1975 (Kartikasari et al. 2013). In the last four years, two new species of Rhododendron have been discovered in New Guinea (James \& Argent 2017, Danet 2015). There are several current botanical explorations in Papua conducted by researchers from Indonesia and also abroad. These include the Rio Tinto project by PT. Freeport Indonesia, Lengguru (Joint Research Indonesia Institute of Science (LIPI), Institute of Research for Development (IRD) French, Sorong fisheries Academy, Dinas Perikanan dan Kelautan Kabupaten Kaimana, Universitas Negeri Papua, Universitas Cendrawasih, and Universitas Musamus), E-Win LIPI and exploration of enrichment of Wamena biology garden collection conducted by BO Staff. (Johns et al. 2006, Juswara et al. 2016, Mambrasar \& Hutabarat 2016, Nugroho et al. 2016).

The specimen Konsterman \& Soegeng 775 (BO), collected on a botanical exploration conducted in the Baliem Valley, Papua Province, Indonesia in 1966. The exploration yielded a specimen of Rhododendron, first identified as $R$. beyerinckianum Koord. After being further studied, it was identified as $R$. gumineense Craven using the key in 'Rhododendron of Subgenus Vireya (Argent 2015). R. gumineense was known only in the 
eastern part of New Guinea and not previously recorded in the western part (Argent 2015, Craven 2014). So, this find is evidance of a much wider distribution of $R$. gumineense. It also increases the number of Rhododendron species recorded from Indonesia to a total of 230 species.

\section{Rhododendron gumineense Craven (Figure 1).}

J. Adelaide Bot. Gard. 2014. 27:31. Type : A. Rouse s.n. 29 Dec. 2012. Cultivated specimen (CANB!, E, MEL).

Shrub to $2,5 \mathrm{~m}$, twig rounded, densely scaly. Leaves 3-5 together in pseudo whorls. Blade $30-53 \times 10-25 \mathrm{~mm}$, broadly elliptic to elliptic, apex obtuse or shortly acuminate; margin revolute; base broadly tapering; scales dense, dendroid; petiole 5-15 mm, densely scaly. Flowers 2-3 together, half hanging. Pedicel $c a .20 \times 1 \mathrm{~mm}$, slender, densely brown-stellate-scaly, without simple hairs. Calyxca. $1 \mathrm{~mm}$ in diameter. Corolla $24-35 \mathrm{~mm}$, pink; tube tubular-curved, moderately scaly outside, glabrous inside; lobes $6 \mathrm{~mm}$ long, scaly outside. Stamens slightly exserted, filaments 28 $\mathrm{mm}$, glabrous; anthers 1-2.8 mm, oblong, light brown. Ovary $8 \times 3 \mathrm{~mm}$, sub-cylindrical, tapering to style, densely scaly; style $20 \mathrm{~mm}$, slightly exerted and approximating the stamens in length, scaly to within $4 \mathrm{~mm}$ of the apex; stigma $c a .2 \mathrm{~mm}$ in diameter.

Distribution: Gumine, Chimbu Province, Papua New Guinea and Baliem Valley, Jayawijaya Regency, Papua Province, Indonesia.

Habitat: Terrestrial, grown in montane forest, $2500 \mathrm{~m}$ asl. Fl. August.

Specimens examined: (Photo) Cultivated in Hawthorn East green house, Victoria Australia, 29 Dec. 2012, A. Rouse s.n. CANB880074 (CANB); W. Irian. Baliem valley, Above Welleey, 29 Aug. 1966. Kostermans \& Soegeng 775 (BO).

Notes: This species was first described from a living collection in Australia, cultivated in Hawthorn East, Victoria in a greenhouse. There is no information about the habitat. It was collected by D. Stanton, of Wollongong, NSW, Australia at Gumine, Chimbu Province, (now Simbu Province) Papua New Guinea in 1971, and sent to the Australian Rhododendron Society, Olinda, Victoria, Australia by L. Searle (Kundiawa, Chimbu Province, PNG) in 1974. Craven (2014) and Argent (2015), give the distribution of $R$. gumineense as only known in Papua New Guinea, not from Indonesian New Guinea. Thus the record of $R$. gumineense from Baliem valley is a new record for the flora of Indonesia.
This species is similar to Rhododendron rarum Schltr. but differs in that the style of $R$. gumineense is scaly whereas that of $R$. rarum always has some simple hairs and the leaves are shorter and broader in relation to their length (Argent 2015). Its also similar to $R$. beyerenkianum, but it differs in having the leaf lamina narrowly elliptic to elliptic, base cuneate and often very narrowly so, apex obtuse or shortly acuminate to very narrowly acute to very narrowly acuminate; and the ovary sub-cylindrical and tapering to the style. In $R$. beyerinckianum the leaf lamina is narrowly ovate, to broadly elliptic, obovate or subcircular, the base broadly tapering to rounded, the apex obtuse, broadly acute, sometimes apiculate; and the ovary elongate conical or subovoid, usually abruptly tapering distally (Craven 2014).

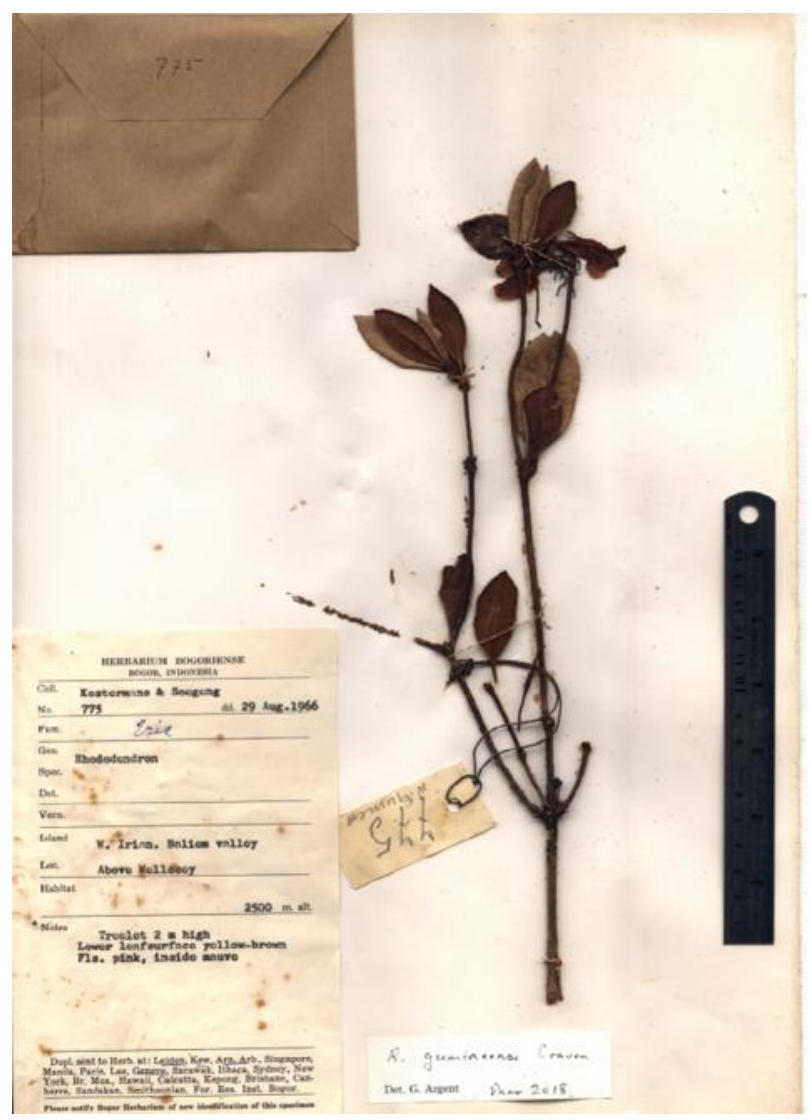

Figure 1. Specimen of $R$. gumineense (Photo: Y. Michael Mambrasar based on Kostermans \& Soegeng 75)

\section{ACKNOWLEDGEMENT}

I would like to thank I Putu Gede Parlida Damayanto, M.Si., Lulut Dwi Sulistyaningsih, M.Si. and Dr. Rugayah are gratefully acknow- 
ledged for critically reading the manuscript.

\section{REFERENCES}

Argent G. 2006. Rhododendrons of subgenus Vireya. 1st edition. Royal Botanic Garden Edinburgh/The Royal Horticultural Society, London, xii $+382 \mathrm{p}$.

Argent G. 2015. Rhododendrons of Subgenus Vireya $2^{\text {nd }}$ Ed. Pp.1-454. Edinburgh.

Beccari O. 1878. Rhododendron, in Beccari O. (ed.), Malesia-raccolta di osservazioni botaniche intorno alle piante dell'arcipelago Indo-Malese e Papuano, vol. 1(3). Tipographia del R. Istituto sordo-muti, Genova: 199 $-207$.

Craven LA. 2014. Three new species of, and realignments in, Rhododendron sect. Schistanthe (Ericaceae). Journal of the Adelaide Botanic Gardens 27: 25-34.

Danet F. 2015. The genus Rhododendron L. (Ericaceae) in New Guinea: a new neotype for $R$. gardenia Schltr. and a new species, Rhododendron cravenii Danet, sp. nov. The Rhododendron 55: 12-26.

Gibbs D, Chamberlain DF \& Agent G. 2011. The Red List of Rhododendrons. Botanic Gardens Conservation International (BGCI). Richmond, UK. p. 128

James SA \& Argent G. 2017. Rhododendron stanleyi S. James \& Argent: A New Rhododenron species (Ericaceae, Subgenus Vireya) From Papua New Guinea. Edinburgh Journal of Botany 74(2): 163-168

Johns RJ, Edwards PJ, Utteridge TMA \& Hopkins HCF. 2006. A Guide to the Alpine and
Subalpine Flora of Mount Jaya. London: Royal Botanic Garden Kew.

Juswara L, Schuiteman A \& Droissart V. 2016. Four new orchid species from the Lengguru fold belt, West Papua, Indonesia. PhytoKeys 2016 (26): 47-59.

Kartikasari EN, Marshall AJ \& Beehler BM. 2013. Ekologi Papua. 2nd edn. Pp.1-981. Jakarta: Yayasan Obor Indonesia dan Concervation Indonesia.

MacKay MB \& Gardiner SE. 2017. Geographic analysis of Red List Rhododendron (Ericaceae) taxa by country of origin identifies priorities for ex situ conservation. Blumea (62): 103-120.

Mambrasar YM \& Hutabarat PWK. 2016. Keragaman Rhododendron Vireya di Kawasan Danau Habbema Papua. Proceding SEMNAS BIOETI KE-4 \& KONGRES PTTI XII. Pp. 744-748.

Nugroho H, Wiantoro S, Riyanto A, Irham M, Santika Y, Yulita KDS, Sadili A, Mambrasar YM, Sumerta IN, Robiansyah I, Muliadi, Priatna Y, Sahroni D, Sumanta I, Muliadi, Narko D, Lestari WS, Peneng IN, Wibowo ARU, Kuswantoro F \& Fauzi A. 2016. Ekspedisi Bioresources 2016. Pp. 135. Bogor. Tambrauw-Papua Barat. Kedeputian Ilmu Pengetahuan Hayati-LIPI.

Sleumer H. 1966. Ericaceae. In: Steenis CGGJ van (ed.) Flora Malesiana Ser. I, Vol. 6: 469914. Nordhoff, Groningen.

Steenis-Kruseman MJ van. 1950. Malaysian plant collectors and collections. Flora Malesiana 1(1): 1-639. Nordhoff, Groningen. 